\title{
Printed carbon based interface for protein immobilization
}

\author{
Grzegorz Wróblewski ${ }^{1}$ (1) - Marta Janczuk-Richter ${ }^{2} \cdot$ Tomasz Wolkowicz $^{3} \cdot$ Malgorzata Jakubowska' \\ Joanna Niedziolka-Jonsson ${ }^{2}$
}

Received: 29 November 2018 / Accepted: 28 May 2019 / Published online: 8 June 2019

(c) The Author(s) 2019

\begin{abstract}
The aim of the investigations was to find a method of protein immobilisation in screen printed graphite layers. Three commonly used graphite powders were used to prepare conductive layers via screen printing. Several printing pastes with different carbon to polymer resin (polymethylmethacrylate) ratios were tested and the composition with the best electrical properties was selected for further investigations related to green fluorescent protein immobilisation. Six different procedures of protein immobilisation were examined including physical adsorption, electrochemical generation of carboxylic groups and 1-ethyl-3-(3-dimethylaminopropyl)carbodiimide activation, graphite functionalisation with succinic anhydride and graphite functionalisation with 3-(triethoxysilyl)propylsuccinic anhydride. Some of the functionalisation procedures were done before printing (functionalisation of graphite powders) and the others were done on printed and cured coatings. Printed graphite layers with immobilised green fluorescent proteins were studied with confocal fluorescent microscopy to assess the efficiency of the immobilisation procedures. The best results were observed for graphite functionalisation with succinic anhydride and 1-ethyl-3-(3-dimethylaminopropyl)carbodiimide activation of carboxylic groups.
\end{abstract}

\section{Introduction}

Protein based interfaces are very important and promising in biosensor market and thus different immobilization solutions are under development. To realize such an interface, proteins need to be attached firmly to the surface. There are several methods reported in the literature, some are irreversible and other reversible. Among the irreversible we can distinguish covalent binding [1-3], cross-linking [4-6], and entrapment [7-9]. The reversible methods of immobilization includes adsorption, both physical binding [10-12] and ionic binding [13], bio-affinity [14, 15], chelation or metal binding $[13,16]$, or disulphide bonds [17]. Proteins may be an active sensing component themselves or may be used as

Grzegorz Wróblewski

g.wroblewski@mchtr.pw.edu.pl

1 Institute of Metrology and Biomedical Engineering, Warsaw University of Technology, A. Boboli 8, 02-525 Warsaw, Poland

2 Institute of Physical Chemistry, Polish Academy of Sciences, Kasprzaka 44/52, 01-224 Warsaw, Poland

3 Department of Bacteriology and Biocontamination Control, National Institute of Public Health - National Institute of Hygiene, Chocimska 23, 00-791 Warsaw, Poland an interconnection for other molecules. The structure and method of operation of the sensor determine if the bioreceptors should be bound to the conductive or insulating surface. Sensors may work for example as dipole antennas where load impedance changes its resonant frequency, return loss and reflected signal [18], then conductive surface with bioreceptors may be implemented. It may be also possible to create sensitive capacitors, where one of plates is functionalised with bioreceptors. Printing methods are one of the low-cost and high yield process that may be used for protein based devices and surfaces. The deposition may be done on rigid (glass, ceramic [19-21]), flexible (PET [22-24], paper [25-27], textiles [28-30]) as well as stretchable (silicone rubber [31-33], polyurethane [34-36]) materials. Moreover patterning to desired shape is possible without development and etching. Thanks to printing deposition and avoiding noble metals it is possible to realize the disposable approach that allows to avoid the regeneration or sterilisation of the sensor surface. Moreover, intensive research around carbonbased materials has led to the synthesis of numerous multifunctional composites based on diverse carbon allotropes such as graphite and graphene [37-39]. Sensing layers in sensors may be printed with diverse printing techniques such as screen printing [40], ink-jet printing [41], flexography [42], gravure [43] or aerosol jet [44]. This layers may be 
already fully functional after printing or may be functionalized to acquire desired properties in additional processes after printing [45].

In this paper we are presenting the results of investigations related to a universal protein interface that can be used for various sensors with different bioreceptors. Our goal was to achieve a conductive graphite-based printed layer functionalised in such a manner that diverse bioreceptors, such as antibodies, enzymes, or peptides, might be attached to achieve desired functionalities of the sensing layer. Moreover, our results may also be applied to surface modifications performed with the aim to control the wettability or other surface properties.

\section{Materials and methods}

Investigated layers were deposited by means of screen printing technique, therefore specially tailored materials in form of screen printing pastes needed to be prepared. Pastes consisted of polymer resin filled with graphite materials.

Firstly $8.0 \mathrm{wt} \%$ polymer resin was prepared by dissolving polymethylmethacrylate (PMMA, Mw $=350,000)$ granulate in carbitol butyl acetate acquired from Dow Chemical Company by means of magnetic stirrer $\left(70^{\circ} \mathrm{C}\right.$ for $12 \mathrm{~h}$ ).

Afterwards diverse dispersions with different graphite powders were prepared. Three common types of graphite powder were used in the experiments: Emperor 2000 (acquired from Cabot Corporation), Vulcan XC72 (acquired from Cabot Corporation), and Graphite powder (GP20), $<20 \mu \mathrm{m}$, synthetic (acquired from Aldrich). Graphite powders, depending of the type, needed diverse concentrations in the paste to achieve good printability. Pastes were printed with the semiautomatic screen printer (Aurel C920) and cured in a chamber dryer $120^{\circ} \mathrm{C}$ for $30 \mathrm{~min}$. Samples were printed on the polyethylene terephthalate (PET) $100 \mu \mathrm{m}$ thick film (3 M, 9962 Diagnostic Microfluidic Hydrophilic Film).

After selecting the best material and composition for the printing pastes (26 wt\% GP20 graphite in PMMA resin) several investigations were done to find the most suitable way of attachment of proteins to the printed graphite layers. To assess the ability of immobilisation eGFP-HisTag-green fluorescent protein (GFP) was used and samples were studied with confocal fluorescent microscopy (Nikon Ti Eclipse with confocal system A1R, ion laser IMA101040AL5 emitting light of wavelength of $488 \mathrm{~nm}$, objective CFI Plan Fluor $\times 40$, and NISElements AR 4.13 software). GFP was delivered to the functionalised graphite surfaces in form of solution $0.01 \mathrm{mg} / \mathrm{mL}$ in phosphate buffered saline (PBS). PBS consists of $0.01 \mathrm{M}$ phosphate buffer, $0.0027 \mathrm{M}$ potassium chloride and $0.137 \mathrm{M}$ sodium chloride, $\mathrm{pH} 7.4$ at $25^{\circ} \mathrm{C}$. Used GFP (EMD Millipore, Merck) has excitation maximum for $488 \mathrm{~nm}$ and emission maximum for $509 \mathrm{~nm}$. To show the morphology of sample surfaces used for immobilisation, Scanning electron microscope (SEM) pictures were taken using FEI Nova NanoSEM 450. Energy dispersive X-ray analysis (EDX) data were obtained using an Octane Elect detector from EDAX with $20 \mathrm{kV}$ beam energy. X-ray photoelectron spectroscopy (XPS) was performed by spectrometer (Microlab 350 Thermo VG Scientific) equipped with a non-monochromated excitation source of $\mathrm{Al} \mathrm{K} \alpha\left(1486.6 \mathrm{eV} ; 300 \mathrm{~W}\right.$, pressure $\left.1.0 \times 10^{-9} \mathrm{mbar}\right)$.

\subsection{Physical adsorption of GFP to printed carbon surface}

First, direct physical adsorption of GFP to printed carbon surface was performed along to scheme presented on Fig. 1. Carbon surface was incubated in GFP solution for $1 \mathrm{~h}$ and then washed with PBS.

\subsection{Electrochemical generation of carboxylic groups and 1-ethyl-3-(3-dimethylaminopropyl) carbodiimide activation}

Secondly, electrochemical generation of carboxylic groups on the carbon surface was performed according to a modified literature procedure [46], along to scheme presented on Fig. 2. Briefly, carbon surface was immersed in $0.1 \mathrm{M}$ sulfuric acid and voltage $+1.6 \mathrm{~V}$ was applied for $180 \mathrm{~s}$. Autolab $302 \mathrm{~N}$ potentiostat was used and ITO-LPG, platinum net, and $\mathrm{Ag} \mid \mathrm{AgCl} 0.1 \mathrm{M} \mathrm{NaCl}$ were used as working, counter, and reference electrodes, respectively. Then the carboxylic groups were activated with 1-ethyl-3-(3-dimethylaminopropyl)carbodiimide (EDC) to enable the reaction of this groups with amine groups present on the surface of the GFP protein. The activation was performed by $15 \mathrm{~min}$ incubation of carbon electrodes in EDC ( $4 \mathrm{mg} / \mathrm{mL})$. Then GFP solution was added for $1 \mathrm{~h}$ to assess the protein immobilisation efficiency.

\subsection{Graphite functionalisation with 3-(triethoxysilyl)propylsuccinic anhydride (TESPSA)}

The third investigated method takes into account the use of TESPSA to create covalent amide bond in ring opening reaction between succinic anhydride present in TESPSA and amine groups present on the surface of the GFP protein. TESPSA, that is usually used for glass surface modifications [47], was

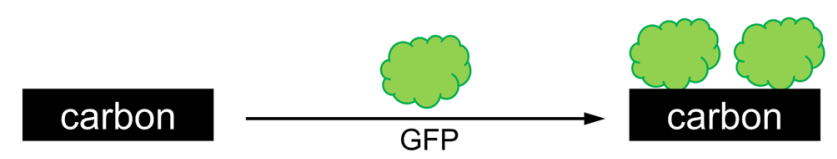

Fig. 1 Scheme of direct physical adsorption of GFP to carbon surface 
here used to introduce succinic anhydride groups into the carbon paste simply by mixing it with other components. The scheme of the method is presented on Fig. 3.

3-(Triethoxysilylpropyl)succinic anhydride (TESPSA) was weighted in various amounts, then graphite and on the end PMMA resin was added in a way to achieve $26 \mathrm{wt} \%$ graphite in polymer resin. Samples with $1 \mathrm{wt} \%$ TESPSA, $5 \mathrm{wt} \%$ TESPSA, $10 \mathrm{wt} \%$ TESPSA in relation to graphite weight were prepared. All compositions were mixed and homogenized in a agate mortar for $20 \mathrm{~min}$ then printed in the same way as described above. Sample with TESPSA used as the only resin was rejected from further studies due to the high autofluorescence.

Printed graphite surfaces with TESPSA were cured in $120{ }^{\circ} \mathrm{C}$ for $1 \mathrm{~h}$ in chamber dryer to dehydrate succinic anhydride groups and then the surface was immersed in GFP solution for $1 \mathrm{~h}$.

\subsection{Graphite functionalisation with TESPSA and EDC activation of carboxylic groups}

The fourth investigated method of GFP immobilisation was similar to described above but EDC was added to activate carboxylic groups prior to modification with GFP. The procedure was performed similar to that described above. The scheme of procedure is presented in Fig. 4.

Printed graphite surfaces with TESPSA were cured in $120^{\circ} \mathrm{C}$ for $1 \mathrm{~h}$ in chamber dryer, then they were incubated in EDC $(4 \mathrm{mg} / \mathrm{mL})$ for $15 \mathrm{~min}$ and at the end GFP protein was delivered to the surface ( $1 \mathrm{~h}$ incubation).

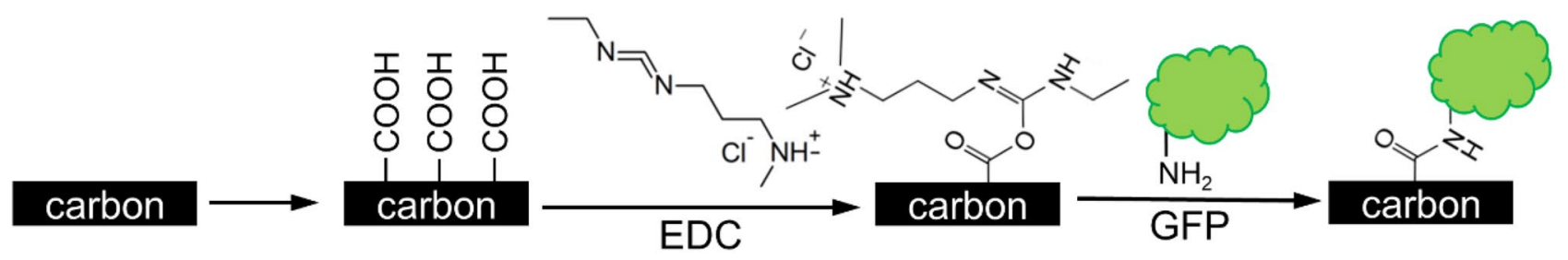

Fig. 2 Scheme of electrochemical generation of carboxylic groups, EDC activation, and GFP immobilization

Fig. 3 Scheme of use of TESPSA to create amide bonding between TESPSA and GFP protein
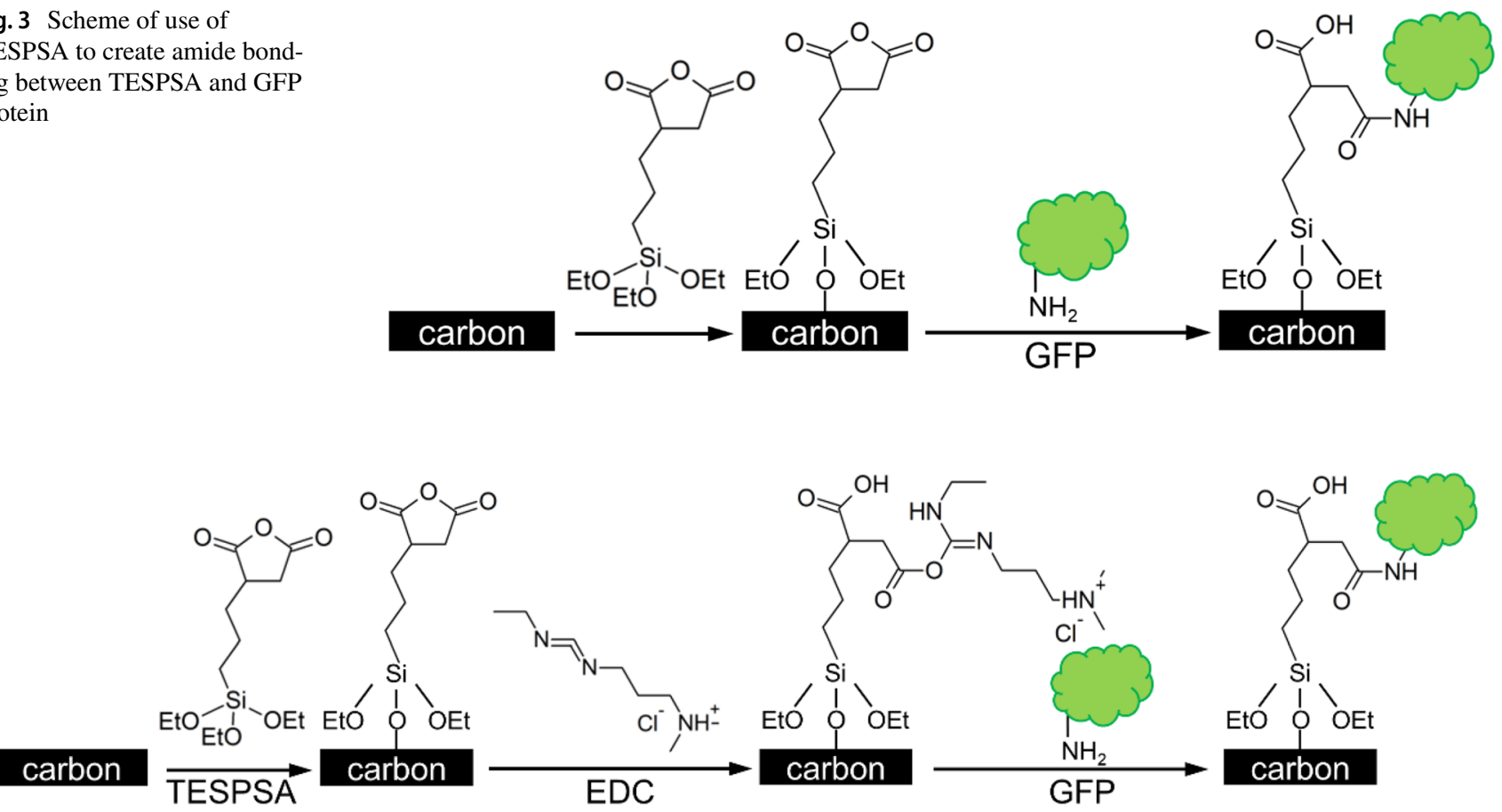

Fig. 4 Scheme of use of TESPSA to create amide bonding between TESPSA and GFP protein. Additionally carboxylic groups were activated with EDC 


\subsection{Graphite functionalisation with succinic anhydride}

The fifth method was including the use of succinic anhydride to introduce carboxylic groups into the carbon material and to create amide bond between succinic anhydride (that gives two carboxylic groups after hydrolysis) and amine groups present on the surface of the GFP protein. The scheme of procedure is presented in Fig. 5.

Succinic anhydride was introduced into printed layers by incubating the graphite powders in succinic anhydride solution before preparing the paste. Three series of samples were prepared: $0.1 \mathrm{mM}, 0.5 \mathrm{mM}, 1.0 \mathrm{mM}$ of succinic anhydride. After $24 \mathrm{~h}$ incubation, modified graphite powders were dried in the oven $\left(80^{\circ} \mathrm{C}\right)$. Functionalized graphite powders were used for printing pastes preparation therefore PMMA resin was added to achieve desired compositions (26 wt $\%$ of graphite in polymer resin).

Printed graphite surfaces with succinic anhydride were cured in $120^{\circ} \mathrm{C}$ for $1 \mathrm{~h}$ in chamber dryer and then GFP protein was delivered to the surface ( $1 \mathrm{~h}$ incubation).

\subsection{Graphite functionalisation with succinic anhydride and 1-ethyl-3-(3-dimethylaminopropyl) carbodiimide activation of carboxylic groups}

The last method investigated during this research was similar to described above but EDC activation of carboxylic groups was added. The scheme of procedure is presented in Fig. 6.

Printed graphite surfaces with succinic anhydride were cured in $120{ }^{\circ} \mathrm{C}$ for $1 \mathrm{~h}$ in chamber dryer, then activated with EDC, and then GFP protein was delivered to the surface (1 $\mathrm{h}$ incubation).

\section{Results and discussion}

Firstly the resistance of printed layers from diverse types of graphite was measured. Since our aim is to use the interface in sensors our goal was to find the composition with the lowest resistance. It is commonly known that when the higher concentration of conductive material occurs the electrical properties are better. Unfortunately for printing there is a limit of conductive phase that can be present after which printing becomes unstable_-paste becomes unprintable and cannot be squeezed through the screen mesh. The graphite paste GP20 was chosen for the experiments because it exhibited the best printing and electrical performance, what could be seen from Fig. 7. For all samples we have observed that after achieving a certain graphite concentration the

Fig. 5 Scheme of use of graphite functionalisation with succinic anhydride to create amide bonding between succinic anhydride and GFP protein
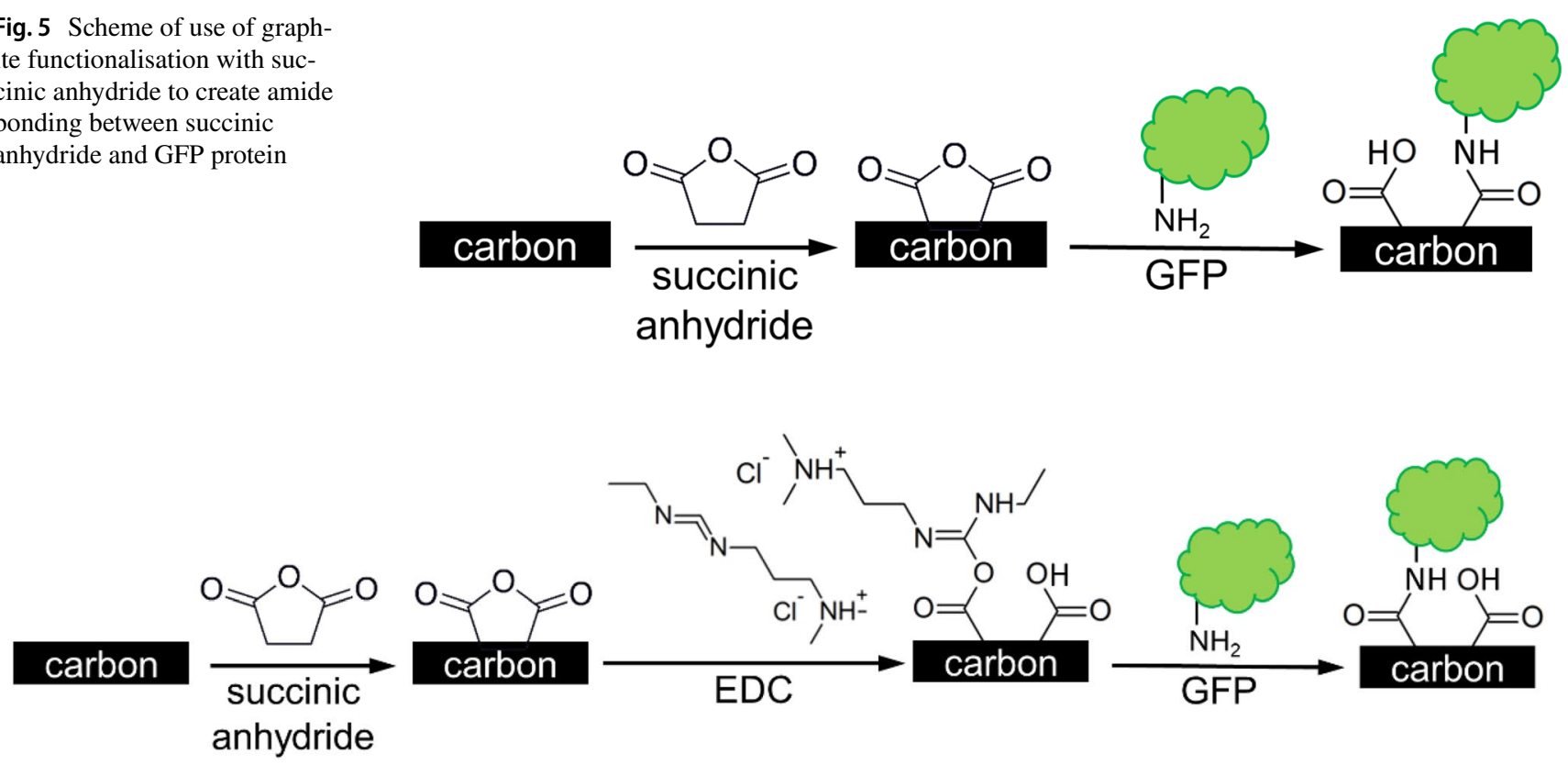

Fig. 6 Scheme of use of graphite functionalisation with succinic anhydride to create amide bonding between succinic anhydride and GFP protein. Additionally carboxylic groups were activated with EDC 
Fig. 7 Sheet resistance and its standard deviation of printed conductive layers with different graphite powders in various concentration

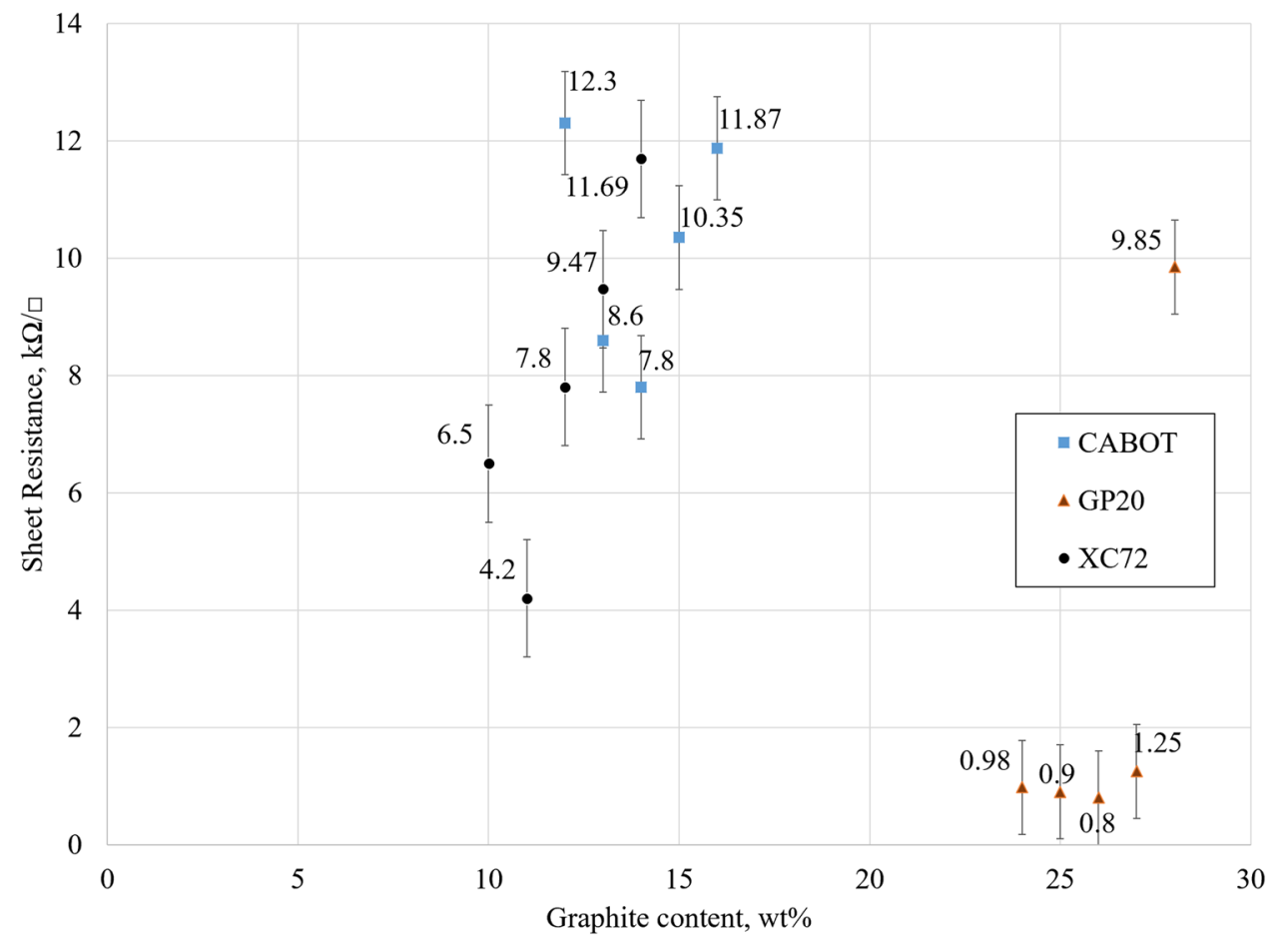

Table 1 Sheet resistance and its standard deviation of printed conductive layers with addition of TESPSA

\begin{tabular}{ll}
\hline Sample composition & $\mathrm{k} \Omega / \square$ \\
\hline $1 \mathrm{wt} \%$ TESPSA + GP20 + PMMA & $2.33 \pm 0.79$ \\
$5 \mathrm{wt} \%$ TESPSA + GP20 + PMMA & $2.38 \pm 0.75$ \\
$10 \mathrm{wt} \%$ TESPSA + GP20 + PMMA & $2.53 \pm 0.81$ \\
$15 \mathrm{wt} \%$ TESPSA + GP20 + PMMA & $3.15 \pm 0.85$ \\
\hline
\end{tabular}

Table 2 Sheet resistance and its standard deviation of printed conductive layers with functionalised graphite powder (GP20)

\begin{tabular}{ll}
\hline GP20 functionalised & $\mathrm{k} \Omega / \square$ \\
\hline $0.1 \mathrm{mM}$ succinic anhydride & $1.00 \pm 0.23$ \\
$0.5 \mathrm{mM}$ succinic anhydride & $1.46 \pm 0.31$ \\
$1.0 \mathrm{mM}$ succinic anhydride & $1.76 \pm 0.32$ \\
\hline
\end{tabular}

resistance started to increase. For the GP20 the best results were achieved for $26 \mathrm{wt} \%$ graphite powders in the printing paste and this composition was used for further investigations.

The second set of measurements was related to the sheet resistance of samples printed from paste made with GP20 graphite, PMMA resin and diverse amounts of TESPSA as described in procedure no 3. The measurements of sheet resistance are presented in Table 1. The higher amount of TESPSA was added the higher sheet resistance was measured. That occurs due to the fact that TESPSA is an insulating component.

Table 2 presents the results from sheet resistance measurements of printed conductive layers with functionalised graphite powder with graphite functionalisation with succinic anhydride as described in procedure no 5. Similar to results above, we have observed that the higher amount of succinic anhydride was used the higher sheet resistance was measured, since succinic anhydride worked also as an insulating phase.

All of samples were also investigated by SEM, EDX and XPS before protein immobilisation. Figure 8a shows a low magnification $(\times 500)$ SEM picture of a reference (non-functionalized) graphite layer. The image shows rough and irregular structure. This is a typical morphology for screen printed composites that gives a well-developed surface favourable for immobilisation techniques. The surface is densely covered with numerous graphite flakes of varying sizes and thicknesses, which can be seen in images with higher magnification (Fig. 8b-d). Similar images to Fig. 8. (nonfunctionalized graphite) were taken for the samples functionalized with the most effective procedure i.e. Graphite functionalisation with succinic anhydride and 1-ethyl-3-(3-dimethylaminopropyl)carbodiimide activation of carboxylic groups (Fig. 9.). Comparing these samples reveals no significant differences in surface morphology which confirms the assumption that the changes were of a chemical nature. Similar results have been observed for all of the others samples functionalized with other methods. 
Fig. 8 SEM pictures of the nonfunctionalized graphite, $\mathbf{a} \times 500$ magnification, $\mathbf{b} \times 5000$ magnification, $\mathbf{c} \times 10,000$ magnification, $\mathbf{d} \times 50,000$ magnification
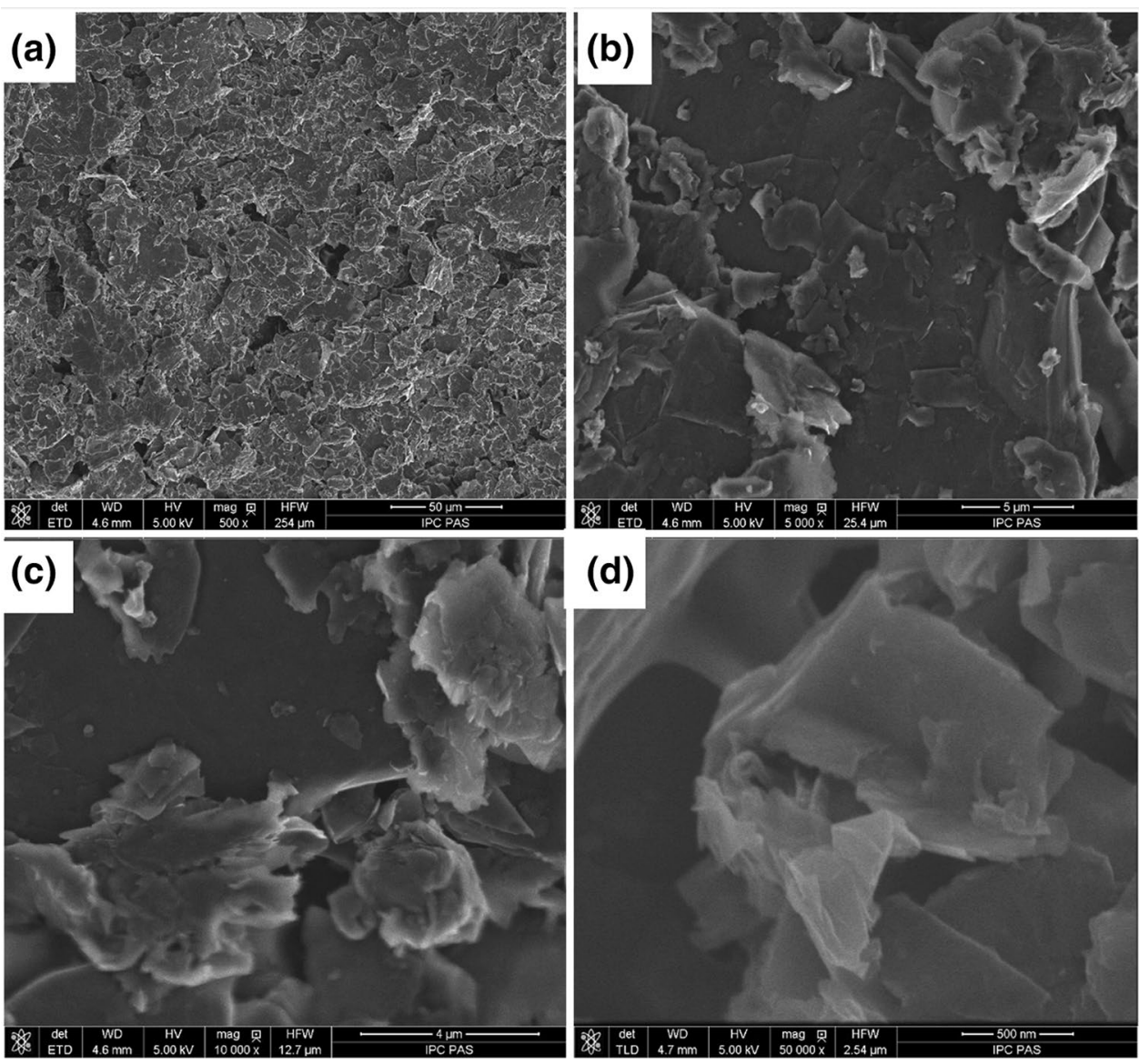

To check that desired functional groups are present on the sample surface, we performed EDX and XPS analysis. Figure 10 shows the EDX results for printed non-functionalized graphite layer and Fig. 11 shows the EDX results for the same graphite material which was treated with TESPSA. Apart from carbon, smaller intensity peaks were observed for oxygen for both samples. In Fig. 11, we see a peak related to silicon which is present in TESPSA, thus it may be assumed that the functionalisation was successful.

Additionally XPS measurements were performed and the atomic percentages of $\mathrm{Si}, \mathrm{O}$ and $\mathrm{C}$ were calculated after curve deconvolution with the help of an asymmetric Gaussian/Lorentzian mixed function. The calculated atomic percentages of detected elements on the surface of the samples are shown in Table 3. As expected, the major component for all of the samples is carbon, from 92.4 atom\% for non-functionalized graphite (GP20) down to 63.4 atom\% for graphite functionalized with $10 \mathrm{wt} \%$ of TESPSA. Other elements detected include oxygen, from 7.5 up to 22.7 atom $\%$, and silicon from 0.1 up to 14.0 atom\% for nonfunctionalized graphite (GP20) and graphite functionalized with $10 \mathrm{wt} \%$ of TESPSA respectively.

The XPS measurements results are consistent with EDX results since graphite was functionalised before printing, thus the functionalisation elements are present not only on the surface but also in the depth of the material. Significantly higher amount of silicon might be seen for TESPSA and higher amount of oxygen for succinic anhydrite. The slight amount of silicon in samples functionalized with succinic anhydride may come from the process of mixing of the printing paste in the mortar which is made from ceramics.

To assess the ability of protein immobilisation to printed functionalized graphite fluorescent microscopy was used since it is the most common and best suited method for this purpose. Figure 12 presents the results from confocal fluorescent microscopy investigations where GFP emitted green light under irradiation with light with $488 \mathrm{~nm}$ wavelength. After preliminary research with protein immobilization on carbon electrodes modified with different amount of TESPSA and succinic anhydride the samples with $1 \mathrm{wt} \%$ TESPSA and $1.0 \mathrm{mM}$ succinic anhydride were chosen. All the samples were imaged with the same parameters. It could be seen that the highest amount of relatively homogeneously distributed GFP was registered for samples prepared along to the procedure no 6, i.e. Graphite functionalisation with succinic anhydride and 1-ethyl-3-(3-dimethylaminopropyl) carbodiimide activation of carboxylic groups. Better results obtained for method 6 (succinic anhydride + EDC) than 
Fig. 9 SEM pictures of graphite functionalized with $10 \mathrm{wt} \%$ of TESPSA, $\mathbf{a} \times 500$ magnification, $\mathbf{b} \times 5000$ magnification, $\mathbf{c} \times 10,000$ magnification, $\mathbf{d}$ $\times 50,000$ magnification

Fig. 10 EDX results for nonfunctionalized graphite (GP20)
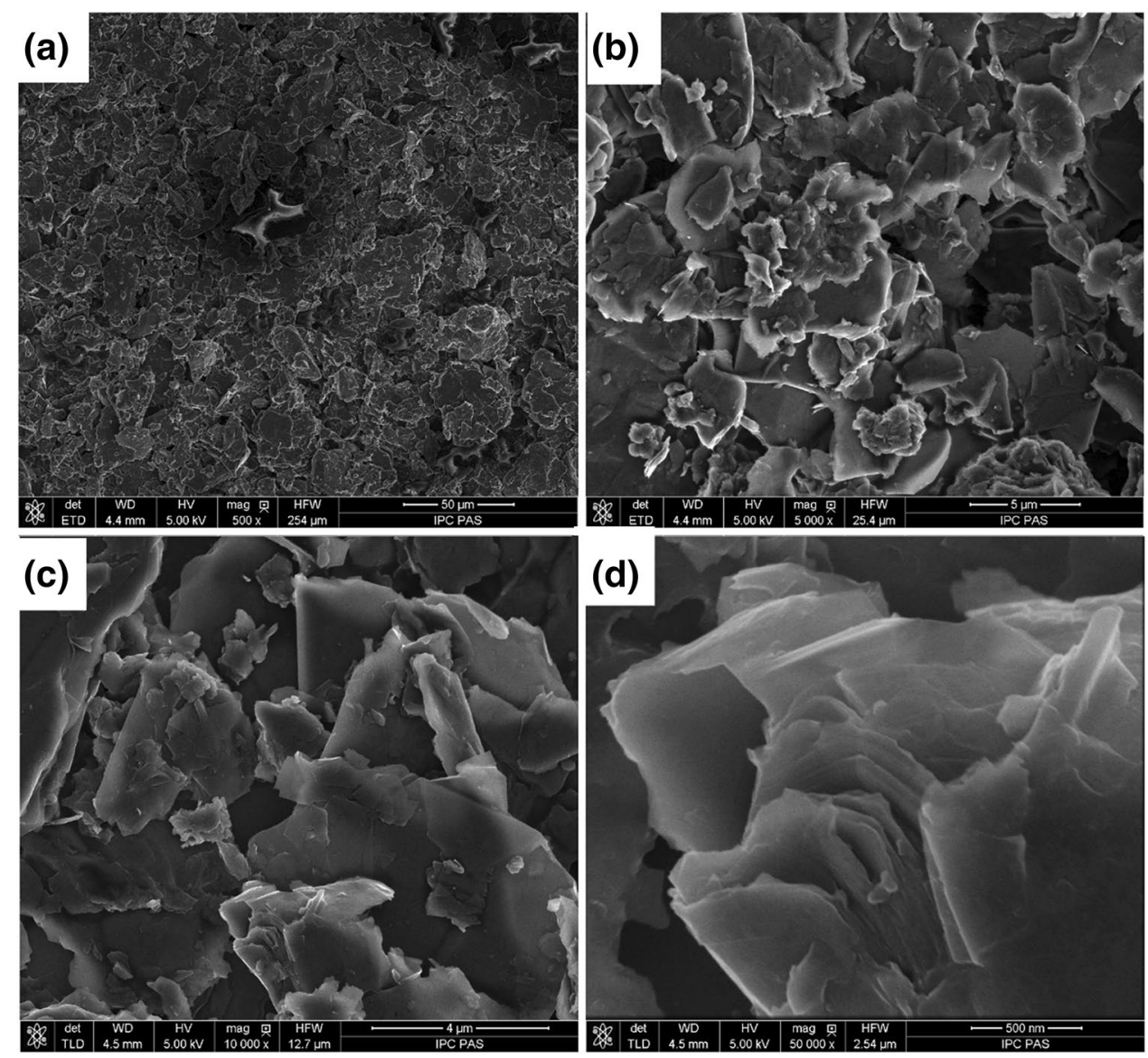

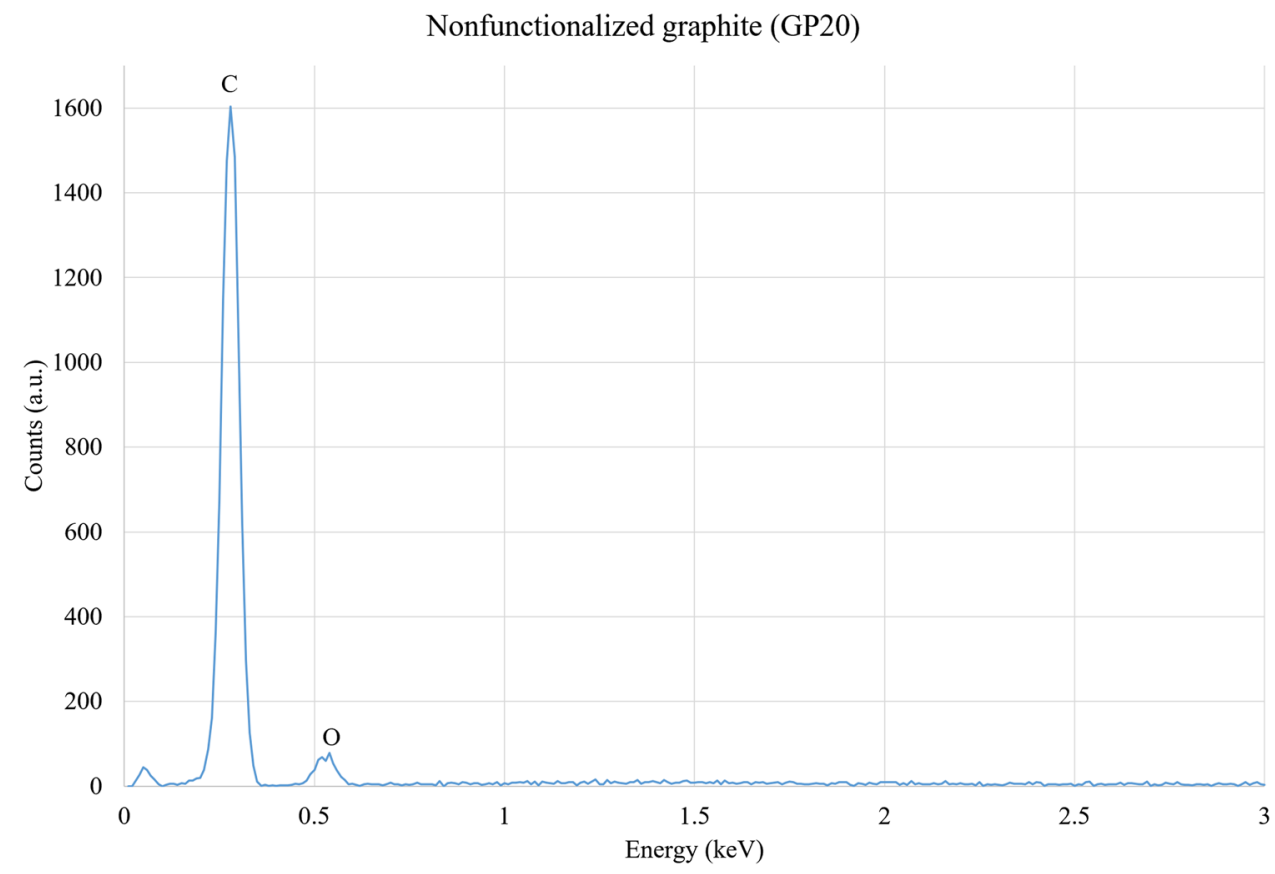


Fig. 11 EDX results for graphite (GP20) functionalized with TESPSA

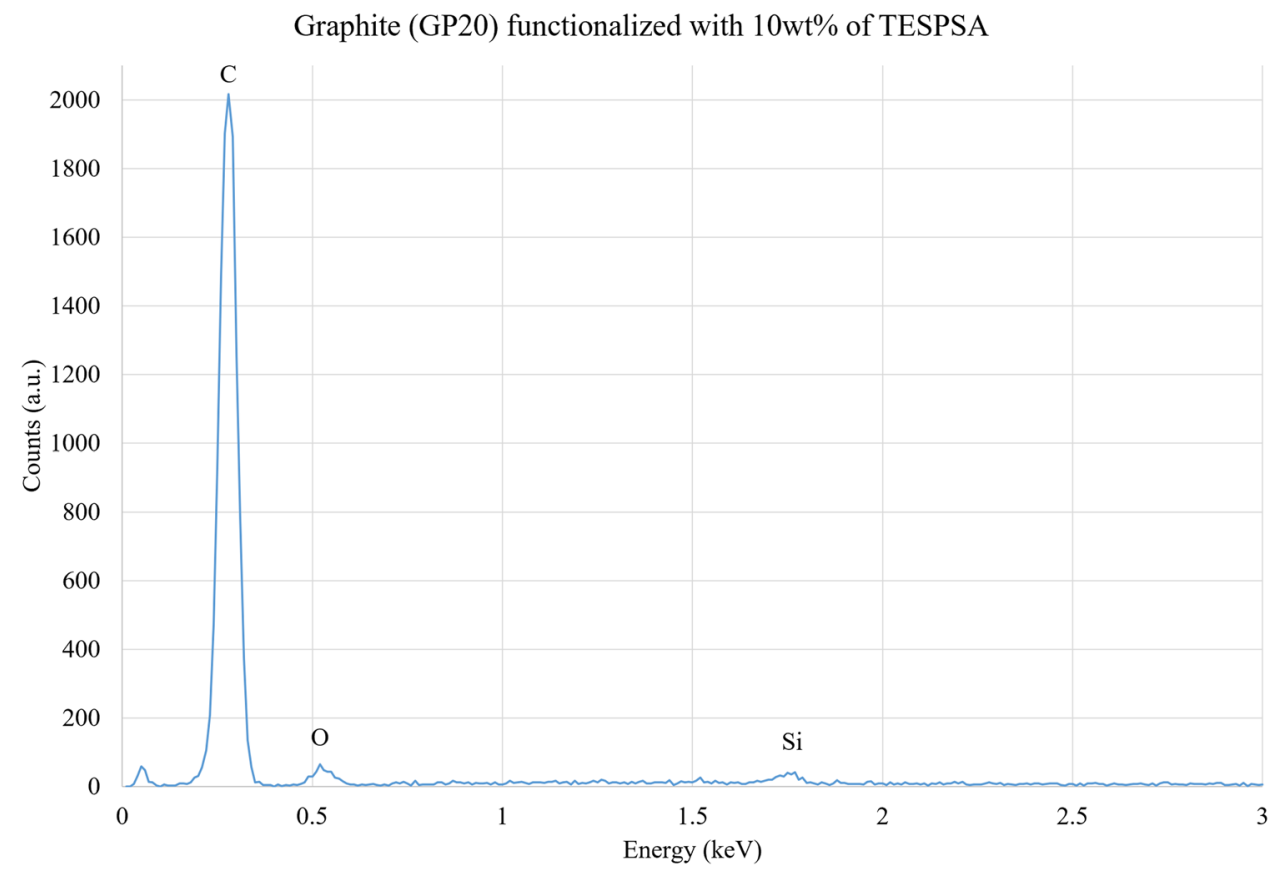

Table 3 Elemental surface compositions determined by XPS (atom\%) for samples taken for protein immobilisation

\begin{tabular}{lrlllc}
\hline Sample & GP20 & $\begin{array}{l}\text { TESPSA } \\
1 \mathrm{wt} \%\end{array}$ & $\begin{array}{l}\text { TESPSA } \\
10 \mathrm{wt} \%\end{array}$ & $\begin{array}{l}0.1 \mathrm{mM} \\
\text { succinic } \\
\text { anhydride }\end{array}$ & $\begin{array}{l}1.0 \mathrm{mM} \\
\text { succinic } \\
\text { anhydride }\end{array}$ \\
\hline Element & & & & & \\
$\mathrm{Si}$ & 0.1 & 2.7 & 14.0 & 0.7 & 0.6 \\
$\mathrm{O}$ & 7.5 & 14.2 & 22.7 & 9.0 & 8.1 \\
$\mathrm{C}$ & 92.4 & 83.1 & 63.4 & 90.2 & 91.4 \\
\hline
\end{tabular}

GP20 refers to nonfunctionalized graphite layer as the reference

method 5 (succinic anhydride) showed that the method of graphite functionalization with succinic anhydride is efficient, but some of the succinic anhydride molecules hydrolysed before incubation in protein solution. Therefore, much more efficient was the method with EDC activation, because both succinic anhydride and carboxyl groups created after hydrolysis can take part in the reaction and the more reactive groups are present on the surface during incubation in protein solution. It could be also seen that similar behaviour was observed for carbon samples with TESPSA and TESPSA with EDC, in which higher GFP immobilization efficiency was obtained for sample with EDC activation. In almost all samples we have also observed agglomerates of GFP but this can be improved by introduction of mixing during incubation in protein solution. The worst effects were registered for procedure no 2 , in which carboxyl groups were generated electrochemically, probably due to the small amount of groups generated this way. The observed results for physisorption were relatively good, but the fact that this method may deliver to weak bonding of proteins does not encourage to use it $[48,49]$.

From the technical point of view, methods where graphite is functionalised prior to printing pastes preparation are easier to apply in large scale than methods where surface processing is performed after printing. It is easier to conduct chemical modifications on powders than on printed layers when masking may be required.

\section{Conclusions}

Investigations described in the present paper show that conductive graphite layers deposited by means of screen printing method may be successfully enriched with proteins. The best results are achieved for procedure where graphite powders are functionalised prior to screen printing paste preparation-procedure no 6 "Graphite functionalisation with succinic anhydride and 1-ethyl-3-(3-dimethylaminopropyl) carbodiimide activation of carboxylic groups". Successful chemical functionalisation effecting in presence of functionalised groups was proven via EDX and XPS analysis. Those functionalised groups are well known and described as a tool for covalent bonding of proteins [43]. Results may be used in i.e., bioelectronic interfaces with active antennas or capacitors or may be applied for tuning of surface properties. Thanks to deposition with printing technique it is easy to coat extensive surfaces with high yield. Moreover it is possible to use diverse substrates, rigid like glass or ceramics as well as flexible like polymer films, papers or textiles. 
Fig. 12 Images from confocal fluorescent microscope showing the efficiency of GFP immobilization on the surface of printed graphite layer. For each method two samples were shown. Scale bar shows $100 \mu \mathrm{m}$
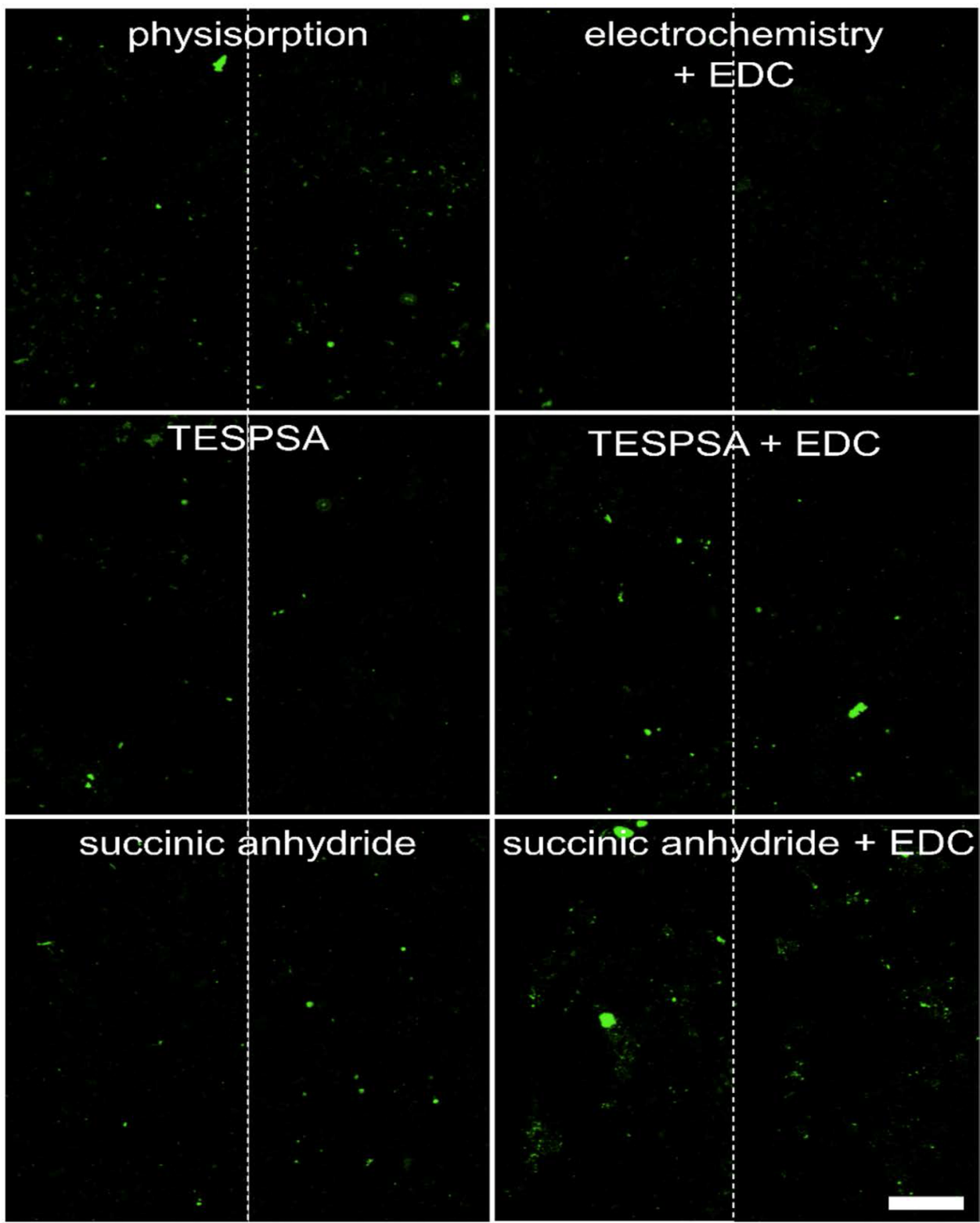

Acknowledgements The research was financially supported in $60 \%$ from funds for research activities of the Institute of Metrology and Biomedical Engineering, Faculty of Mechatronics, Warsaw University of Technology (Poland), and in 40\% from the project 3/DOT/2016 funded by the City of Gdynia (Poland).

Open Access This article is distributed under the terms of the Creative Commons Attribution 4.0 International License (http://creativeco mmons.org/licenses/by/4.0/), which permits unrestricted use, distribution, and reproduction in any medium, provided you give appropriate credit to the original author(s) and the source, provide a link to the Creative Commons license, and indicate if changes were made.

\section{References}

1. B.R. Coad, M. Jasieniak, S.S. Griesser, H.J. Griesser, Surf. Coat. Technol. 233, 169 (2013)

2. V. Müller, J. Rathousky, D. Fattakhova-Rohlfing, Electrochim. Acta 116, 1 (2014)

3. Z. Qu, K. Chen, H. Gu, H. Xu, Bioconjug. Chem. 25, 370 (2014)

4. S.K.S. Patel, S.V. Otari, J. Li, D.R. Kim, S.C. Kim, B.K. Cho, V.C. Kalia, Y.C. Kang, J.K. Lee, J. Hazard. Mater. 347, 442 (2018)

5. T. Iype, J. Thomas, S. Mohan, K.K. Johnson, L.E. George, L.A. Ambattu, A. Bhati, K. Ailsworth, B. Menon, S.M. Rayabandla, R.A. Jesudasan, S. Santhosh, C.N. Ramchand, Anal. Biochem. 519, 42 (2017)

6. R. Shaimi, S.C. Low, J. Polym. Eng. 36, 655 (2016)

7. Y. Jia, X. Zuo, X. Lou, M. Miao, Y. Cheng, X. Min, X. Li, F. Xia, Anal. Chem. 87, 3890 (2015) 
8. X.P. He, Y. Zang, T.D. James, J. Li, G.R. Chen, Chem. Soc. Rev. 44, 4239 (2015)

9. X. Hu, P. Cebe, A.S. Weiss, F. Omenetto, D.L. Kaplan, Mater. Today 15, 208 (2012)

10. J. Guo, R. Zhong, W. Li, Y. Liu, Z. Bai, J. Yin, J. Liu, P. Gong, X. Zhao, F. Zhang, Appl. Surf. Sci. 359, 82 (2015)

11. A.M.L. Sousa, T.-D. Li, S. Varghese, P.J. Halling, K.H.A. Lau, A.C.S. Appl, Mater. Interfaces 10, 39353 (2018)

12. O.V. Morozova, O.N. Volosneva, O.A. Levchenko, N.A. Barinov, D.V. Klinov, Mater. Sci. Forum 936, 42 (2018)

13. T. Dudev, C. Lim, Chem. Rev. 114, 538 (2014)

14. S. Liebana, G.A. Drago, Essays Biochem. 60, 59 (2016)

15. G.F. Bickerstaff, Immobilized Enzyme Cells (Humana Press, New Jersey, 1997), pp. 1-12

16. K.J. Waldron, J.C. Rutherford, D. Ford, N.J. Robinson, Nature 460, 823 (2009)

17. G. Bulaj, Biotechnol. Adv. 23, 87 (2005)

18. S.D. Jang, J. Kim, Smart Mater. Struct. 21, 025002 (2012)

19. R. Zhou, J. Li, H. Jiang, H. Li, Y. Wang, D. Briand, M. Camara, G. Zhou, N.F. de Rooij, Sens. Actuators B Chem. 281, 212 (2019)

20. G. Korotcenkov, Handbook of Gas Sensor Materials (Springer, New York, 2013), pp. 249-254

21. M. Dietze, M. Es-Souni, Sens. Actuators A Phys. 143, 329 (2008)

22. D. Janczak, A. Peplowski, G. Wroblewski, L. Gorski, E. Zwierkowska, M. Jakubowska, J. Sensors 2017, 6 (2017)

23. G. Dubourg, A. Segkos, J. Katona, M. Radović, S. Savić, G. Niarchos, C. Tsamis, V. Crnojević-Bengin, G. Dubourg, A. Segkos, J. Katona, M. Radović, S. Savić, G. Niarchos, C. Tsamis, V. Crnojević-Bengin, Sensors 17, 1854 (2017)

24. S.G.R. Avuthu, J.T. Wabeke, B.B. Narakathu, D. Maddipatla, J.S. Arachchilage, S.O. Obare, M.Z. Atashbar, IEEE Sens. J. 16, 8678 (2016)

25. S. Cinti, N. Colozza, I. Cacciotti, D. Moscone, M. Polomoshnov, E. Sowade, R.R. Baumann, F. Arduini, Sens. Actuators B Chem. 265, 155 (2018)

26. T. Rungsawang, E. Punrat, J. Adkins, C. Henry, O. Chailapakul, Electroanal. 28, 462 (2016)

27. S. Cinti, D. Talarico, G. Palleschi, D. Moscone, F. Arduini, Anal. Chim. Acta 919, 78 (2016)

28. M. Stoppa, A. Chiolerio, Sensors 14, 11957 (2014)

29. M. Parrilla, R. Cánovas, I. Jeerapan, F.J. Andrade, J. Wang, Adv. Healthc. Mater. 5, 996 (2016)

30. G. Paul, R. Torah, S. Beeby, J. Tudor, Sens. Actuators A Phys. 206, 35 (2014)

31. D. Cotton, I.M. Graz, S.P. Lacour, IEEE Sens. 9, 2008 (2009)

32. S. Harada, W. Honda, T. Arie, S. Akita, K. Takei, ACS Nano 8, 3921 (2014)
33. A.S. Kurian, T. Giffney, J. Lee, J. Travas-Sejdic, K.C. Aw, Electroact. Polym. Actuators Devices 9798, 97980 (2016)

34. M. Ali, D. Maddipatla, B.B. Narakathu, A.A. Chlaihawi, S. Emamian, F. Janabi, B.J. Bazuin, M.Z. Atashbar, Sens. Actuators A Phys. 274, 109 (2018)

35. J. Suikkola, T. Björninen, M. Mosallaei, T. Kankkunen, P. IsoKetola, L. Ukkonen, J. Vanhala, M. Mantysalo, Sci. Rep. 6, 25784 (2016)

36. S. Chen, X. Shan, W. L. R. Tang, B. M. Mohaime, M. H. Goh, Z. W. Zhong, J. Wei, Electronics Packaging Technology Conference (EPTC) 19th, 1 (2017)

37. H. Kooshki, A. Sobhani-Nasab, M. Eghbali-Arani, F. Ahmadi, V. Ameri, M. Rahimi-Nasrabadi, Sep. Purif. Technol. 211, 873 (2019)

38. A. Khoshroo, L. Hosseinzadeh, A. Sobhani-Nasab, M. RahimiNasrabadi, H. Ehrlich, J. Electroanal. Chem. 823, 61 (2018)

39. H.R. Naderi, A. Sobhani-Nasab, M. Rahimi-Nasrabadi, M.R. Ganjali, Appl. Surf. Sci. 423, 1025 (2017)

40. A. Hayat, J.L. Marty, Sensors 14, 10432 (2014)

41. P. Sjöberg, A. Määttänen, U. Vanamo, M. Novell, P. Ihalainen, F.J. Andrade, J. Bobacka, J. Peltonen, Sens. Actuators B Chem. 224, 325 (2016)

42. D. Maddipatla, B.B. Narakathu, S.G.R. Avuthu, S. Emamian, A. Eshkeiti, A.A. Chlaihawi, B.J. Bazuin, M.K. Joyce, C.W. Barrett, M.Z. Atashbar, IEEE Sensors 2015, 1 (2015)

43. Y. Lin, L. Huang, L. Chen, J. Zhang, L. Shen, Q. Chen, W. Shi, Sens. Actuators B Chem. 216, 176 (2015)

44. S. Li, J.G. Park, S. Wang, R. Liang, C. Zhang, B. Wang, Carbon 73, 303 (2014)

45. J. Amani, M. Maleki, A. Khoshroo, A. Sobhani-Nasab, M. Rahimi-Nasrabadi, Anal. Biochem. 548, 53 (2018)

46. S. Patris, P. De Pauw, M. Vandeput, J. Huet, P. Van Antwerpen, S. Muyldermans, J.M. Kauffmann, Talanta 130, 164 (2014)

47. A. Gang, G. Gabernet, L.D. Renner, L. Baraban, G. Cuniberti, RSC Adv. 5, 35631 (2015)

48. L. Bayne, R.V. Ulijn, P.J. Halling, Chem. Soc. Rev. 42, 9000 (2013)

49. M. Hartmann, X. Kostrov, Chem. Soc. Rev. 42, 6277 (2013)

Publisher's Note Springer Nature remains neutral with regard to jurisdictional claims in published maps and institutional affiliations. 